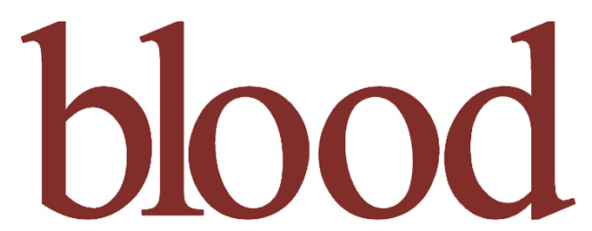

2008 112: 3563-3573

Prepublished online Aug 6, 2008;

doi:10.1182/blood-2008-03-144667

\title{
HMG-CoA reductase inhibition induces IL-12 release through Rac1/PI3K/PKB-dependent caspase-1 activation
}

Loes M. Kuijk, Jeffrey M. Beekman, Janet Koster, Hans R. Waterham, Joost Frenkel and Paul J. Coffer

Updated information and services can be found at:

http://bloodjournal.hematologylibrary.org/cgi/content/full/112/9/3563

Articles on similar topics may be found in the following Blood collections:

Chemokines, Cytokines, and Interleukins (565 articles)

Information about reproducing this article in parts or in its entirety may be found online at: http://bloodjournal.hematologylibrary.org/misc/rights.dtl\#repub_requests

Information about ordering reprints may be found online at:

http://bloodjournal.hematologylibrary.org/misc/rights.dt|\#reprints

Information about subscriptions and ASH membership may be found online at: http://bloodjournal.hematologylibrary.org/subscriptions/index.dtl

Blood (print ISSN 0006-4971, online ISSN 1528-0020), is published semimonthly by the American Society of Hematology, 1900 M St, NW, Suite 200, Washington DC 20036.

Copyright 2007 by The American Society of Hematology; all rights reserved.

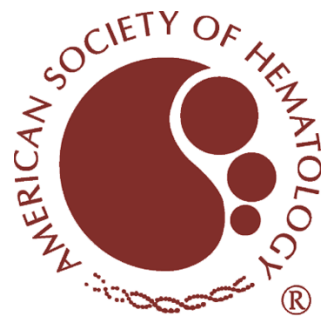




\title{
HMG-CoA reductase inhibition induces IL-1 $\beta$ release through Rac1/PI3K/PKB-dependent caspase-1 activation
}

\author{
Loes M. Kuijk, ${ }^{1,2}$ Jeffrey M. Beekman, ${ }^{2}$ Janet Koster, ${ }^{3}$ Hans R. Waterham, ${ }^{3}$ Joost Frenkel, ${ }^{1}$ and Paul J. Coffer ${ }^{2,4}$ \\ Departments of ${ }^{1}$ General Pediatrics and ${ }^{2}$ Pediatric Immunology, University Medical Centre, Utrecht; ${ }^{3}$ Laboratory of Genetic Metabolic Diseases, Departments of \\ Clinical Chemistry and Pediatrics, Emma Children's Hospital, Academic Medical Centre, Amsterdam; and 4Molecular Immunology Lab, Department of \\ Immunology, University Medical Centre, Utrecht, The Netherlands
}

\begin{abstract}
Mevalonate kinase deficiency (MKD) is an autoinflammatory disorder characterized by recurring fever episodes and results from disturbed isoprenoid biosynthesis. Lipopolysaccharide-stimulated peripheral blood mononuclear cells from MKD patients

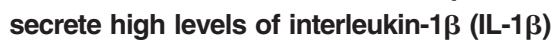
because of the presence of hyperactive caspase-1, and this has been proposed to be the primary cause of recurring inflammation. Here we show that inhibition of HMG-CoA reductase by simvastatin treatment, mimicking MKD, results in in-
\end{abstract}

creased IL-1 $\beta$ secretion in a Rac1/PI3Kdependent manner. Simvastatin treatment was found to activate protein kinase B (PKB)/c-akt, a primary effector of PI3K, and ectopic expression of constitutively active PKB was sufficient to induce IL-1 $\beta$ release. The small GTPase Rac1 was activated by simvastatin, and this was required for both PKB activation and IL-1 $\beta$ secretion. IL-1 $\beta$ release is mediated by caspase-1, and simvastatin treatment resulted in increased caspase-1 activity in a Rac1/PI3K-dependent manner. These data suggest that, in MKD, dysregulated isoprenoid biosynthesis activates Rac1/PI3K/ $\mathrm{PKB}$, resulting in caspase-1 activation with increased IL-1 $\beta$ release. Importantly, inhibition of Rac1 in peripheral blood mononuclear cells isolated from MKD patients resulted in a dramatic reduction in IL-1 $\beta$ release. These data suggest that pharmacologic inhibition of Rac1 could provide a novel therapeutic strategy for treatment of MKD. (Blood. 2008;112: 3563-3573)

\section{Introduction}

Mevalonate kinase deficiency (MKD; MIM \#260920) is an autoinflammatory disorder characterized by spontaneous and recurrent fever attacks. The febrile attacks are accompanied by painful cervical lymphadenopathy and often by abdominal pain, vomiting, and diarrhea. A variety of other symptoms, including headache, skin rashes, mucosal ulcers, myalgia, and arthralgia, may also occur. ${ }^{1-3}$ MKD is inherited in an autosomal recessive manner and is caused by mutations in the gene $M V K$, which codes for the enzyme mevalonate kinase. ${ }^{4,5}$ Mevalonate kinase is a critical enzyme in the isoprenoid biosynthesis pathway, which produces cholesterol and a number of non-sterol isoprenoids. ${ }^{6,7}$ The latter includes geranylgeranylpyrophosphate, a fatty acid side chain that is covalently attached to proteins of the Rho GTPase superfamily. ${ }^{8,9}$ The isoprenoid biosynthesis pathway can be perturbed by the use of statins, which strongly inhibit 3-hydroxy-3-methylglutaryl CoA (HMG-CoA) reductase, the enzyme that catalyzes the conversion of HMG-CoA into mevalonate. ${ }^{7}$ Recently, we and others have shown that impairment of the isoprenoid pathway by statins can augment interleukin-1 $\beta$ (IL-1 $\beta$ ) secretion by activated peripheral blood mononuclear cells (PBMCs). ${ }^{10-12}$ In PBMCs from MKD patients, it is the specific lack of geranylgeranylated proteins that results in increased IL- $1 \beta$ production. ${ }^{13}$ This IL- $1 \beta$ production may be largely responsible for the inflammation and fever observed in MKD patients, a notion that is strongly supported by the successful treatment of MKD patients with the IL-1 receptor antagonist Anakinra (Kineret, Amgen, Thousand Oaks, CA). ${ }^{14-16}$
However, it remains unclear how reduced levels of geranylgeranylated proteins can lead to increased IL-1 $\beta$ release.

To investigate the molecular mechanisms underlying increased IL-1 $\beta$ production in mevalonate kinase deficiency, we have used the monocytic cell line THP-1 in which the isoprenoid biosynthesis pathway is artificially impaired using simvastatin. In this model, simvastatin treatment results in increased IL- $1 \beta$ release by lipopolysaccharide (LPS)-stimulated THP-1 cells. Previous research suggests a 2-step model in which LPS stimulation is needed for efficient transcription of the IL-1 $\beta$ gene, resulting in high levels of intracellular proIL-1 $\beta$ protein. ${ }^{17,18}$ The second step is provided by impairment of the isoprenoid biosynthesis pathway via simvastatin, which strongly enhances proteolytic activity of caspase- $1 .{ }^{19}$ Active caspase- 1 can subsequently process the LPS-induced proIL-1 $\beta$ protein into mature IL-1 $\beta$, which is then secreted together with the caspase-1 subunits.

To investigate the molecular pathways regulating simvastatininduced activation of caspase-1, we have analyzed the signal transduction routes involved in LPS/simvastatin-mediated IL-1 $\beta$ release. Taken together, our data demonstrate that simvastatin treatment results in caspase-1 activation through a Rac1/PI3K/ protein kinase $\mathrm{B}(\mathrm{PKB})$-dependent pathway and that inhibition of Rac1 can decrease IL-1 $\beta$ release by MKD PBMCs. In addition, we found that LPS augments IL- $1 \beta$ transcription via p38 MAPKmediated regulation of the transcription factor NF- $\kappa$ B. These findings provide novel insights into the molecular mechanisms
Submitted March 11, 2008; accepted July 23, 2008. Prepublished online as Blood First Edition paper, August 6, 2008; DOI 10.1182/blood-200803-144667.

The online version of this article contains a data supplement.
The publication costs of this article were defrayed in part by page charge payment. Therefore, and solely to indicate this fact, this article is hereby marked "advertisement" in accordance with 18 USC section 1734.

(C) 2008 by The American Society of Hematology 
responsible for fever and inflammation in MKD patients and define Rac1 as a molecule for potential targeted therapy.

\section{Methods}

\section{Reagents}

Glycogen synthase kinase 3 (GSK-3) inhibitor SB216763, NF-кB inhibitor CAPE, simvastatin, mevalonate, and LPS (Escherichia coli 0127:B8) were purchased from Sigma-Aldrich (St Louis, MO). Simvastatin, dissolved in ethanol, and mevalonate were prepared by hydrolyzation with $0.1 \mathrm{M}$ of $\mathrm{NaOH}$, followed by neutralization with $1 \mathrm{M} \mathrm{N}$-2-hydroxyethylpiperazine$\mathrm{N}^{\prime}$-2-ethanesulfonic acid, $\mathrm{pH} 7.4$, and $0.1 \mathrm{M} \mathrm{HCl}$. The solution was sterilized by filtration through a $0.2-\mu \mathrm{m}$ filter and stored as aliquots at $-20^{\circ} \mathrm{C}$. Rac1 inhibitor, Akt inhibitor VIII, protein kinase $\mathrm{C}$ zeta $\left(\mathrm{PKC}_{\zeta}\right)$ pseudosubstrate, MEK1/2 inhibitor U0126, and NF-кB activation inhibitor II were obtained from Calbiochem (San Diego, CA). Mammalian target of rapamycin (mTOR) inhibitor rapamycin and PI3-kinase inhibitor LY294002 were from BIOMOL Research Laboratories (Plymouth Meeting, PA) and p38 MAPK inhibitor SB203580 from Kordia Life Sciences (Leiden, The Netherlands). Primary antibodies to p-p38 MAPK, p-PKB, total PKB, total p38, total IкB, p-NF-kB, p-eIF4B, p-GSK-3, and p-S6 ribosomal protein were purchased from Cell Signaling Technology (Danvers, MA). Antiactin and antigoat IgG were obtained from Santa Cruz Biotechnology (Santa Cruz, CA).

\section{Cell culture}

Cells were cultured in RPMI 1640 (Invitrogen, Carlsbad, CA) containing $2 \mathrm{mM}$ glutamine, $100 \mathrm{U} / \mathrm{mL}$ penicillin-streptomycin, and either $5 \%$ or $0.1 \%$ fetal calf serum at a density of $10^{6} / \mathrm{mL}$. Incubations were performed at $37^{\circ} \mathrm{C}$ in a humidified atmosphere containing $5 \% \mathrm{CO}_{2}$, in the presence or absence of $10 \mu \mathrm{M}$ simvastatin. After 24 hours of incubation, LPS at a final concentration of $200 \mathrm{ng} / \mathrm{mL}$ was added to the cells. When inhibitors were used, they were added either 1 hour before simvastatin or 1 hour before LPS treatment. After 4 hours of LPS stimulation, supernatants were removed and frozen at $-20^{\circ} \mathrm{C}$. Cell pellets were snap frozen in liquid nitrogen and stored at $-80^{\circ} \mathrm{C}$ for reverse-transcribed polymerase chain reaction (RT-PCR) analysis. Cell lysates were prepared either by direct lysis in $4 \times$ sample buffer or by adding lysis buffer to the cell pellets $(150 \mathrm{mM} \mathrm{NaCl}, 20 \mathrm{mM}$ $\mathrm{N}$-2-hydroxyethylpiperazine- $\mathrm{N}^{\prime}$-2-ethanesulfonic acid, $10 \mathrm{mM}$ ethylenediaminetetraacetic acid, $1 \%$ Triton X-100, protease inhibitors). Cell pellets were then lysed for 30 minutes on ice, after which samples were centrifuged at $13000 \mathrm{~g}$ for 15 minutes. Supernatants were transferred to fresh tubes. Protein levels were determined using the Bio-Rad protein assay (Bio-Rad, Hercules, CA).

\section{Cytokine measurements}

Cytokine detection was carried out using commercially available enzymelinked immunosorbent assay (ELISA) kits: Pelikine-compact human IL-1 $\beta$ ELISA kit (Sanquin, Amsterdam, The Netherlands), human proIL-1 $\beta / I L-$ 1F2, and human caspase-1 Quantikine ELISA Kit (R\&D Systems, Minneapolis, MN). The assays were performed according to the manufacturer's instructions, and all samples were measured in duplicate.

\section{Western blot analysis}

Cell lysates were resolved on sodium dodecyl sulfate polyacrylamide gels and transferred onto polyvinylidene difluoride membranes (Millipore, Billerica, MA). As a control for equal transfer of protein, the blots were stained reversibly with Ponceau S. Membranes were blocked in Tris-buffered saline containing $0.3 \%$ Tween and 5\% nonfat dry milk. Membranes were probed with a 1:1000 dilution of the primary antibody and with a 1:3000 dilution of horseradish peroxidase-conjugated secondary antibody (Dako, Glostrup, Denmark). Chemiluminescence was detected with an enhanced chemoluminescence kit (GE Healthcare, Little Chalfont, United Kingdom).

\section{Viral transduction of THP- 1 cells}

A bicistronic retroviral DNA construct was used, expressing PKBcaax and an Internal Ribosomal Entry Site followed by the gene encoding eGFP (LZRS-eGFP). LZRS-eGFP retrovirus was produced by transient transfection as previously described. ${ }^{20}$ After transfection, viral supernatants were collected, filtered through a $0.2-\mu \mathrm{m}$ filter, and snap frozen in liquid nitrogen. THP-1 cells were transduced in 24-well plates precoated overnight with $10 \mu \mathrm{g} / \mathrm{cm}^{2}$ recombinant human fibronectin fragment $\mathrm{CH}-296$ (RetroNectin, Takara, Japan) in phosphate-buffered saline. Transduction was performed by addition of $0.5 \mathrm{~mL}$ viral supernatant to $0.5 \mathrm{~mL}$ culture medium containing $4 \times 10^{5}$ cells $/ \mathrm{mL}$. Approximately 16 hours after transduction, $0.7 \mathrm{~mL}$ medium was removed from the cells and $0.5 \mathrm{~mL}$ fresh virus supernatant was added together with $0.5 \mathrm{~mL}$ fresh medium. eGFPpositive cells were sorted on a FACS Vantage and cultured in RPMI 1640 containing $50 \mu \mathrm{M} \beta$-mercaptoethanol, $40 \mathrm{U} / \mathrm{mL}$ penicillin, $40 \mu \mathrm{g} / \mathrm{mL}$ streptomycin, and $10 \%$ fetal bovine serum.

\section{GTPase pulldown assay}

The activity of Rac1 was determined with the EZ-Detect Rac1 Activation Kit (Pierce Chemical, Rockford, IL). Briefly, a GST fusion protein containing the p21-binding domain of human Pak1 was used to specifically precipitate the active, GTP-bound, Rac1. ${ }^{21}$ This binding domain was coupled to glutathione-S-transferase. Using glutathione beads, GTP-bound Rac1 was precipitated.

\section{Lactate dehydrogenase assay}

THP-1 cells were cultured for 24 hours in the presence or absence of simvastatin $(20 \mu \mathrm{M})$ and stimulated for an additional 4 hours with $200 \mathrm{ng} / \mathrm{mL}$ LPS. After treatment the cells were thoroughly resuspended, and $200 \mu \mathrm{L}$ cell suspension was used for the CytoTox 96 NonRadioactive Cytotoxicity Assay (Promega, Madison, WI). The assays were performed according to the manufacturer's instructions, and all samples were tested in duplicate.

\section{Quantitative real-time RT-PCR analysis}

The relative expression level of IL-1 $\beta$ to $\beta$-actin RNA was measured with the LightCycler system (Roche Diagnostics, Indianapolis, IN). Total RNA was isolated from THP-1 cells with Trizol extraction. First-strand cDNA was prepared using the first-strand cDNA synthesis kit for RT-PCR according to the manufacturer's instructions. The IL- $1 \beta$ and $\beta$-actin fragments were amplified using the following primer sets: IL-1 $\beta \mathrm{FW}$ 5'-AGA AGA ACC TAT CTT CTT CGA C-3', IL-1 $\beta$ Rev 5'-ACT CTC CAG CTG TAG AGT GG-3', $\beta$-actin Fw $5^{\prime}$-GGC ACC AGG GCG TGA TGG- $3^{\prime}$ and $\beta$-actin Rev $5^{\prime}$-GTC TCA AAC ATG ATC TGG GTC- $3^{\prime}$. Data were analyzed using LightCycler Software, version 3.5 (Roche Diagnostics), and the program LinRegPCR, version 7.5, for analysis of real-time PCR data. To adjust for variations in the amount of input RNA, the IL-1 $\beta$ mRNA levels were normalized against the mRNA levels of the housekeeping gene $\beta$-actin.

\section{PBMC cell culture}

After approval by the ethics review board of the University Medical Centre and after written informed consent was obtained from their parents in accordance with the Declaration of Helsinki, blood was drawn from 2 patients with MKD and from 3 healthy volunteers. PBMCs were isolated by density gradient centrifugation using Ficoll-Paque (GE Healthcare). Isolated PBMCs were cultured in RPMI 1640 (Invitrogen) containing $2 \mathrm{mM}$ glutamine, $100 \mathrm{U} / \mathrm{mL}$ penicillin-streptomycin, and $10 \%$ fetal calf serum. Cells (at a density of $10^{6} / \mathrm{mL}$ ) were seeded in 96-well microtiter plates in the presence or absence of LY294002 or Rac1 inhibitor. Incubations were performed at $37^{\circ} \mathrm{C}$ in a humidified atmosphere containing $5 \% \mathrm{CO}_{2}$. After LPS stimulation, supernatants were removed and stored at $-20^{\circ} \mathrm{C}$.

\section{Statistics}

All results are expressed as the mean plus or minus SEM. In Figures 1, 5C, and 6, statistical significance was calculated using a 1-sample $t$ test. 
A

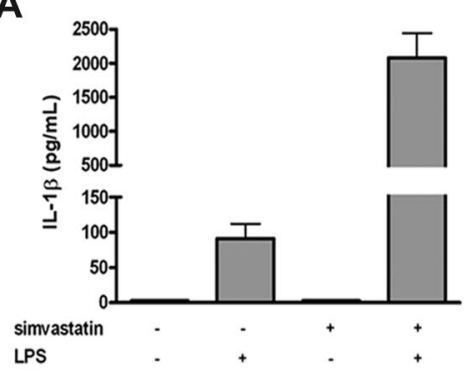

B
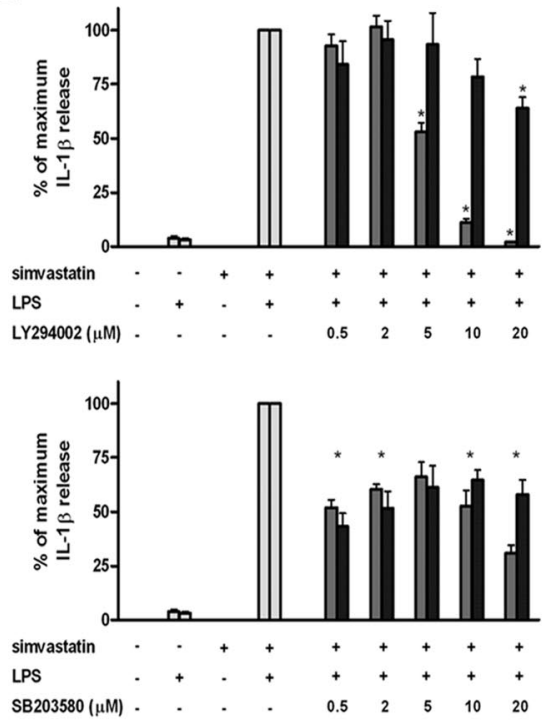

C

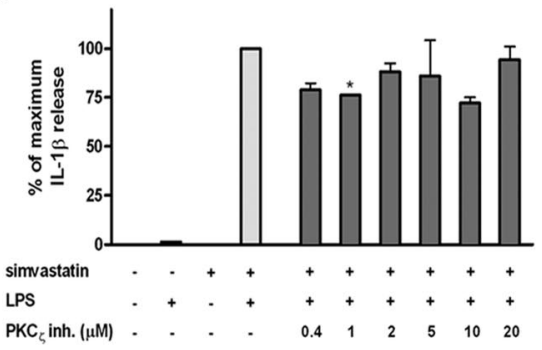

D
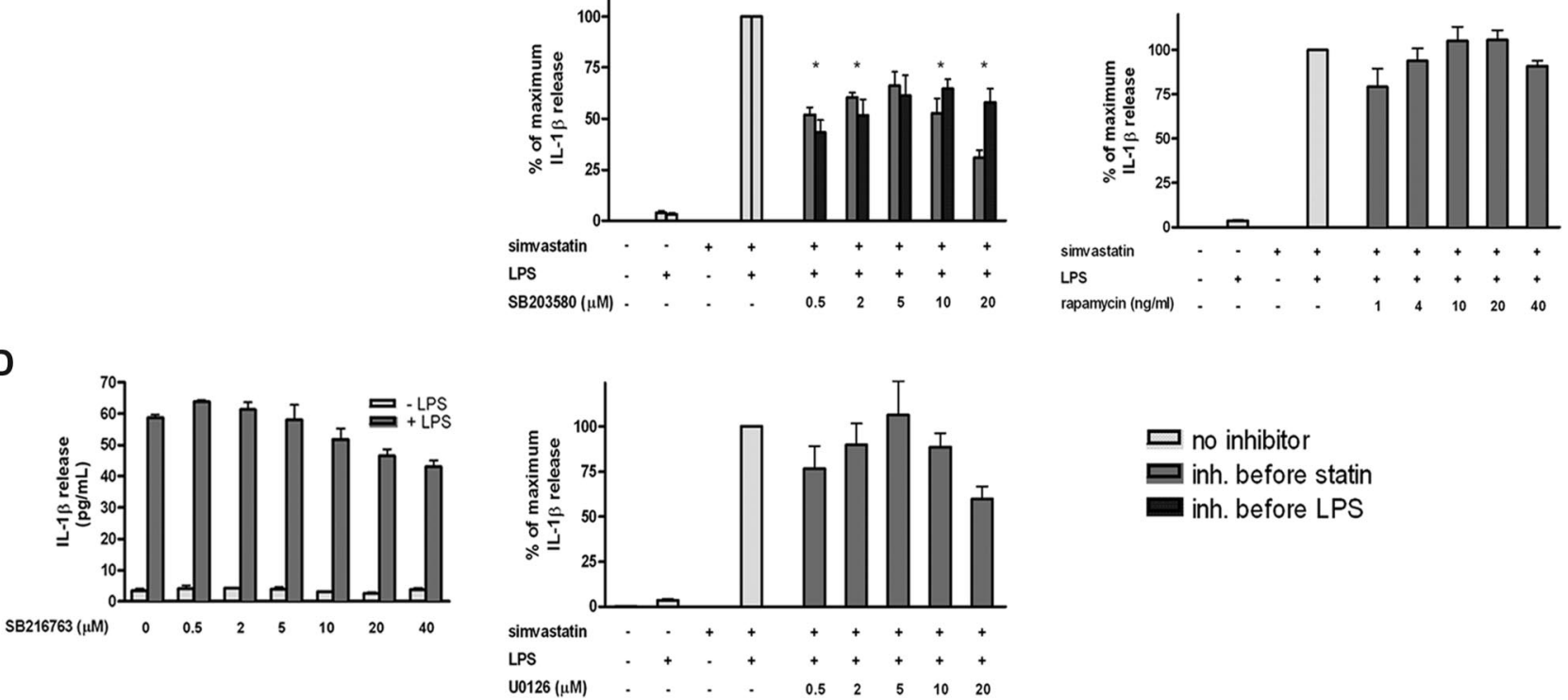

$\begin{array}{llllllll}\mathrm{SB} 216763(\mu \mathrm{M}) & 0 & 0.5 & 2 & 5 & 10 & 20 & 40\end{array}$

U0126 $(\mu \mathrm{M})$

$\begin{array}{lllll}0.5 & 2 & 5 & 10 & 20\end{array}$

Figure 1. PI3K and p38 MAPK are involved in simvastatin-enhanced IL-1 $\beta$ secretion. THP-1 cells were cultured for 24 hours in the presence or absence of simvastatin $(10 \mu \mathrm{M})$ and stimulated for an additional 4 hours with $200 \mathrm{ng} / \mathrm{mL}$ LPS. When inhibitors were used, they were added either 1 hour before simvastatin or 1 hour before LPS treatment. Release of IL-1 $\beta$ was determined by ELISA; data are mean plus or minus SEM. (A) Absolute levels of IL-1 $\beta$ secretion $(n=8)$. (B) Relative inhibition of IL-1 $\beta$ secretion by PI3-kinase, p38 MAPK, and MEK1/2 inhibitors ( $n=4, n=4$, and $n=3$, respectively). (C) Relative inhibition of IL-1 $\beta$ secretion by PKC $\zeta$ and mTOR inhibitors ( $n=3$ and $n=4$, respectively). (D) Induction of LPS-induced IL-1 $\beta$ secretion by a GSK-3 inhibitor $(n=2)$. ${ }^{*}<.01$ compared with $100 \%$. There was no significant effect of the solvent DMSO, as demonstrated in Figure S2.

According to the Bonferroni correction, significance level was set at .01. In Figure $5 \mathrm{~B}$, the Wilcoxon signed-rank test was used with a significance level of .05. All other data were analyzed using 1-way analysis of variance, followed by Tukey multiple comparison test, also with a significance level of .05 .

\section{Results}

\section{PI3K and p38 MAPK regulate LPS/simvastatin-mediated IL-1 $\beta$ secretion}

To induce IL- $1 \beta$ secretion, THP- 1 cells were cultured for 24 hours in the presence or absence of simvastatin and stimulated for an additional 4 hours with LPS, as described before for both PBMCs and THP-1 cells, ${ }^{11,19}$ THP-1 cells stimulated with LPS in the presence of statin, to inhibit HMG-CoA reductase, displayed dramatically increased IL- $1 \beta$ release compared with LPS stimulation alone (Figure 1A). Incubation with statin alone did not induce detectable IL-1 $\beta$ release. The statin-induced effect was specific for IL- $1 \beta$ because IL- 6 and tumor necrosis factor- $\alpha$ release was not significantly affected ${ }^{19}$ (Figure S1, available on the Blood website; see the Supplemental Materials link at the top of the online article). To investigate the potential role of intracellular signal transduction pathways in simvastatin-enhanced activation of IL-1 $\beta$ release,
THP-1 cells were treated with a variety of kinase inhibitors before treatment with simvastatin (Figure 1B). Inhibition of PI3K (LY294002) and p38 MAPK (SB203580) both inhibited IL-1 $\beta$ release when administered before simvastatin, whereas inhibition of MEK1/2 (U0126) had no significant effect. To discern whether the observed inhibition was the result of a simvastatin-mediated or an LPS-mediated effect, the inhibitors were also administered after statin treatment, before addition of LPS (Figure 1B). Inhibition of PI3K no longer had an effect on IL-1 $\beta$ release, whereas the effect of p38 MAPK inhibition was still evident. This suggests that, whereas PI3K activity is crucial for statin-enhanced IL- $1 \beta$ release, p38 MAPK is required for LPS-mediated IL-1 $\beta$ release.

To further investigate the downstream mediators responsible for statin-mediated IL-1 $\beta$ release, several downstream targets of PI3K activation were also investigated. THP-1 cells were treated with inhibitors of mTOR (rapamycin), $\mathrm{PKC}_{\zeta}$ (pseudosubstrate), and GSK-3 (SB216763) 1 hour before addition of simvastatin (Figure 1C,D). Because GSK-3 activity is inhibited rather than activated after PI3K activation, THP-1 cells were only stimulated with LPS to determine whether GSK-3 inhibition could mimic the effect of simvastatin treatment on IL-1 $\beta$ release. None of these inhibitors had an effect on IL-1 $\beta$ release, demonstrating that PI3K-mediated effects are independent of $\mathrm{PKC}_{\zeta}, \mathrm{mTOR}$, or GSK-3 activities. 


\section{Regulation of p38 MAPK and PKB activation by LPS and simvastatin}

Inhibition of PI3K decreases simvastatin-mediated IL-1 $\beta$ release, whereas p38 MAPK inhibition perturbs IL-1 $\beta$ release in an LPS-dependent manner (Figure 1B). To determine whether indeed HMG-CoA reductase inhibition results in PI3K activation, we analyzed the phosphorylation of $\mathrm{PKB} / \mathrm{c}$-akt, which we have previously demonstrated is directly dependent on PI3K activity. ${ }^{22}$ Furthermore, we analyzed whether LPS treatment could indeed enhance phosphorylation of p38 MAPK. THP-1 cells were serumstarved and subsequently stimulated with either LPS or with simvastatin. Cell extracts were analyzed for phospho-p38 MAPK and phospho-PKB content (Figure 2). Incubation of THP-1 cells with simvastatin induced phosphorylation of PKB, whereas no change in the level of phospho-p38 MAPK was observed (Figure 2A). Simvastatin-induced PKB phosphorylation was inhibited by addition of the PI3K inhibitor LY294002 (Figure 2B). In contrast, stimulation of THP-1 cells with LPS induced a time-dependent increase in phospho-p38 MAPK, reaching a maximum at 1 hour, after which levels slowly declined. During this time, no change in phospho-PKB was observed (Figure 2C). These results further support the hypothesis that inhibition of HMG-CoA reductase by simvastatin treatment stimulates IL- $1 \beta$ secretion via a PI3K/PKBdependent pathway whereas LPS enhances IL-1 $\beta$ secretion in a p38 MAPK-dependent manner.

\section{p38 MAPK inhibition decreases prolL-1 $\beta$ transcription and translation}

p38 MAPK inhibition was shown to reduce LPS-driven IL-1 $\beta$ secretion to approximately $60 \%$ of the maximum (Figure 1B). LPS has been described to increase the level of IL-1 $\beta$ transcription, ${ }^{18,23}$ although the exact molecular mechanism involved remains relatively undefined. To determine whether p38 MAPK is indeed required for LPS-induced IL- $1 \beta$ transcription in our model, IL-1 $\beta$ mRNA levels were determined. THP-1 cells were treated with LPS for up to 8 hours in the presence or absence of p38 MAPK inhibitor SB203580. In parallel, levels of proIL-1 $\beta$ protein were determined using a specific proIL-1 $\beta$ ELISA assay (Figure 3). Inhibition of p38 MAPK resulted in a significant delay in IL-1 $\beta$ transcription as shown by the initial inhibition of total IL-1 $\beta$ mRNA levels followed by a recovery (Figure 3A). This pattern was similar for the proIL-1 $\beta$ protein levels (Figure $3 \mathrm{~B}$ ). These data indicate that p38 MAPK indeed plays a role in LPS-induced IL-1 $\beta$ transcription.

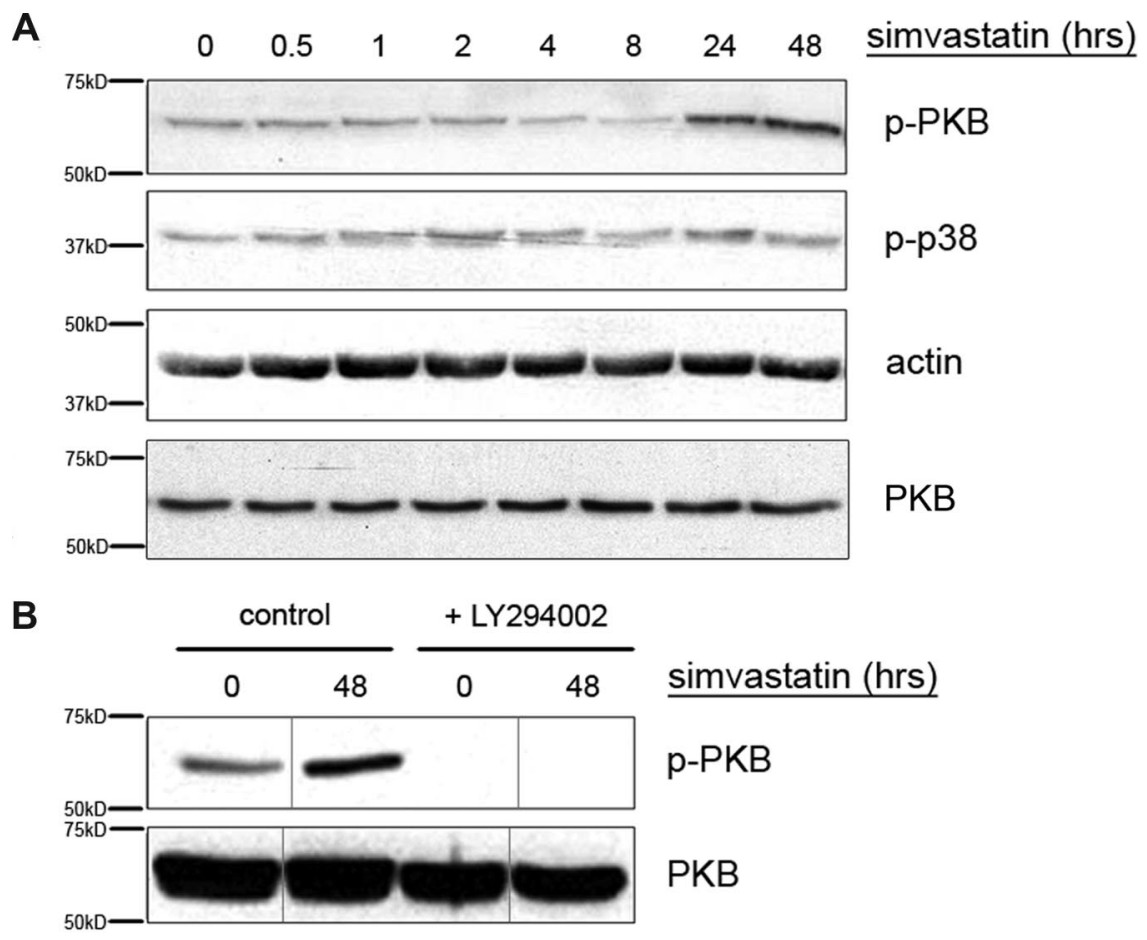

C

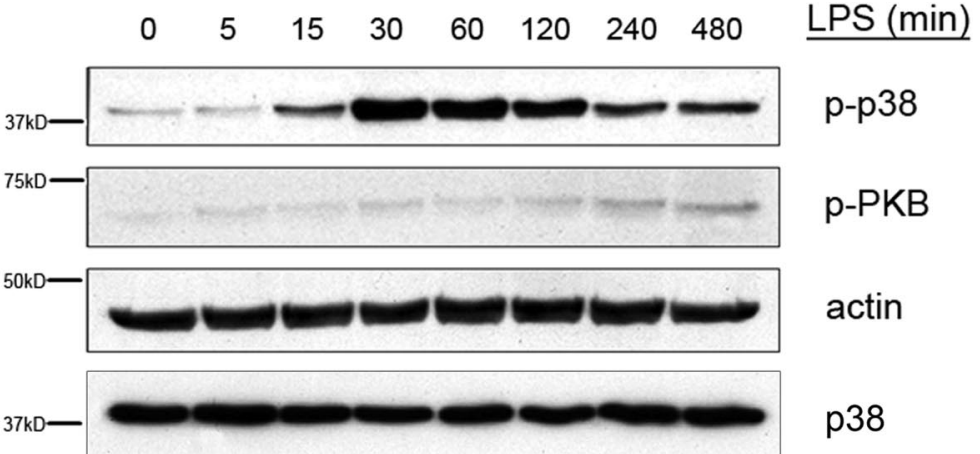

Figure 2. LPS induces p38 MAPK, while simvastatin induces PKB phosphorylation. THP-1 cells were serum-starved overnight and subsequently cultured in the presence of LPS $(200 \mathrm{ng} / \mathrm{mL})$ for up to 8 hours $(C)$ or simvastatin $(10 \mu \mathrm{M})$ for up to 48 hours (A). (B) LY294002 was added 1 hour before simvastatin. Cells were lysed by adding hot sample buffer. Cell lysates were assayed for (phospho-) p38 MAPK and (phospho-) PKB content. Actin content served as control for equal protein loading. Vertical lines have been inserted to indicate a repositioned gel lane, within the same gel. Shown are representative blots of at least 4 independent experiments. 

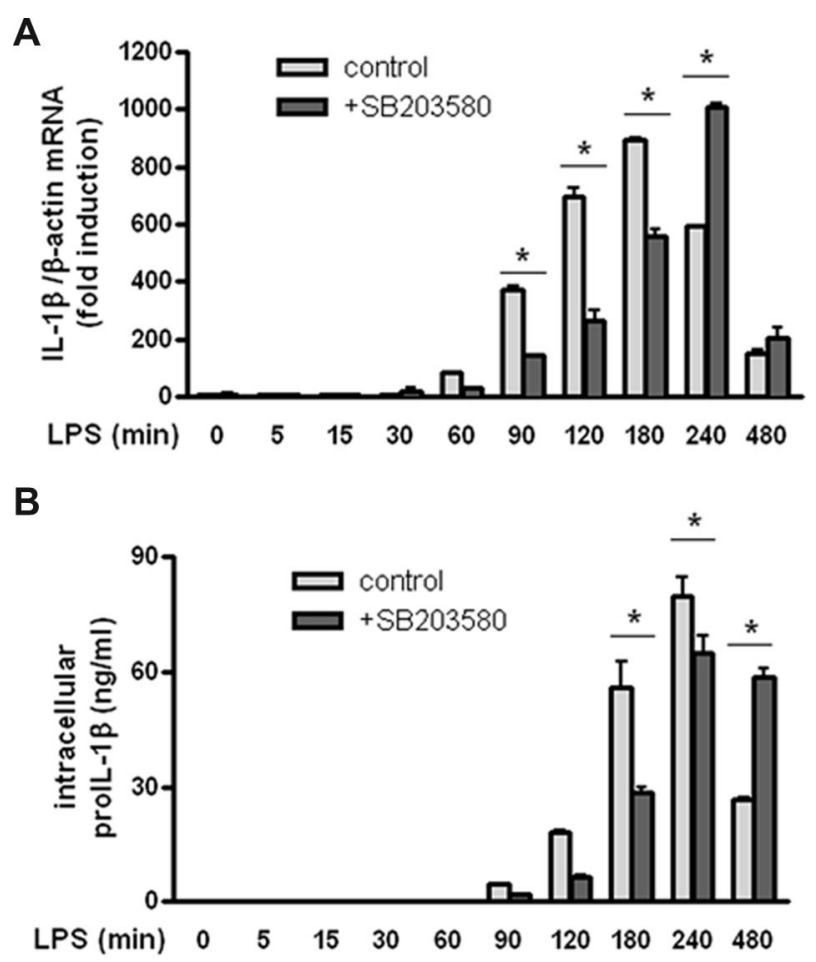

Figure 3. p38 MAPK inhibition decreases prolL-1 $\beta$ transcription and translation. THP-1 cells were cultured in the presence of LPS $(200 \mathrm{ng} / \mathrm{mL})$ for up to 8 hours. p38 MAPK inhibitor was added 1 hour before LPS treatment. Cells were either snap frozen for determination of IL-1 $\beta$ mRNA content $(A)$ or lysed by adding lysis buffer for determination of prolL- $1 \beta$ protein levels $(B)$. Data are mean plus or minus SEM. Data shown are from 1 of 2 experiments performed in duplicate $\left({ }^{*} P<.05\right)$.

\section{LPS-enhanced transcription of IL-1 $\beta$ is mediated via NF-KB}

Several reports have shown that NF-кB can be regulated by $\mathrm{p} 38$ MAPK activity. ${ }^{24,25} \mathrm{NF}-\kappa \mathrm{B}$ is present in the cytoplasm in an inactive complex containing I $\mathrm{B}$ and $2 \mathrm{NF}-\kappa \mathrm{B}$ subunits. When IкB is phosphorylated, it becomes ubiquitinated and subsequently degraded. ${ }^{26}$ During or after phosphorylation of $\mathrm{I} \kappa \mathrm{B}, \mathrm{NF}-\kappa \mathrm{B}$ is phosphorylated and translocates to the nucleus, where it enhances transcription of its target genes. We wanted to determine whether p38 MAPK might play a role in LPS-mediated IL-1 $\beta$ release through activation of NF-кB. Therefore, THP-1 cells were treated with LPS in the presence or absence of p38 MAPK inhibitor SB203580. As a measure of NF- $\mathrm{B}$ activation, we analyzed the levels of $\mathrm{I} \kappa \mathrm{B}$ (Figure $4 \mathrm{~A}$ ), where degradation of $\mathrm{I} \kappa \mathrm{B}$ is an indication of NF- $\kappa$ B activation. In the absence of SB203580, LPS induced $\mathrm{I} \kappa \mathrm{B}$ degradation and this degradation correlated with the increase in p38 MAPK phosphorylation observed earlier (Figure $2 \mathrm{C}$ ), peaking after 1 hour of LPS stimulation. Inhibition of p38 MAPK prevented LPS-mediated І $\mathrm{B}$ degradation, demonstrating that indeed p38 MAPK activation is required for NF- $\kappa$ B activation. In addition, we wanted to establish whether p38 MAPK can also regulate NF- $\kappa$ B phosphorylation (Figure 4B). LPS induced phosphorylation of NF- $\mathrm{B}$, peaking after 1 hour of LPS stimulation. The phosphorylation of NF- $\mathrm{B}$ was not inhibited by SB203580, indicating that phosphorylation of NF-кB is independent of $\mathrm{p} 38$ MAPK activity. To confirm that NF- $\kappa \mathrm{B}$ activity is required for LPS-mediated IL-1 $\beta$ secretion, we incubated THP-1 cells with 2 disparate $\mathrm{NF}-\kappa \mathrm{B}$ inhibitors 1 hour before LPS stimulation and measured IL-1 $\beta$ secretion (Figure $4 \mathrm{C}$ ). Both NF- $\kappa \mathrm{B}$ inhibitors decreased IL- $1 \beta$ secretion in a dose-dependent manner, confirming that NF- $\kappa \mathrm{B}$ activity is required for LPS-mediated IL- $1 \beta$ release.

\section{Ectopic expression of constitutively active PKB enhances IL-1 $\beta$ secretion}

In Figure 2A, we show that PKB is phosphorylated in a timedependent manner after treatment with simvastatin. To determine whether activation of PKB is sufficient to recapitulate the effects of statin treatment on IL- $1 \beta$ secretion, THP- 1 cells were retrovirally transduced with a constitutively active form of PKB (PKBcaax) ${ }^{27}$ or an eGFP control vector. Retroviral transduction resulted in approximately equal levels of PKBcaax compared with endogenous PKB (Figure 5A). Increased PKB activity was confirmed by analysis of phospho-PKB itself and of phosphorylated downstream PKB substrates, including eukaryotic initiation factor 4B (eIF4B), S6 ribosomal protein, and GSK-3 (Figure 5A). Transduced THP-1 cells were incubated with simvastatin for 24 hours and subsequently stimulated with LPS, after which IL-1 $\beta$ secretion was measured. Ectopic expression of constitutively active PKB induced a significant, 2-fold, increase in IL-1 $\beta$ secretion by LPS-stimulated THP- 1 cells. In the presence of both LPS and simvastatin, constitutively active PKB also induced a significant increase in IL-1 $\beta$ secretion (Figure 5B), which, considering the high levels of IL-1 $\beta$ being produced might approach a maximal level, being limited by the capacity of caspase-1 processing. These data suggest that PKB is required, although not sufficient, for simvastatin-mediated activation of IL-1 $\beta$ secretion. This finding was confirmed when wild-type THP-1 cells were incubated with a specific PKB inhibitor before simvastatin treatment (Figure 5C). Inhibition of PKB decreased IL-1 $\beta$ release in a dose-dependent manner. Taken together, these data suggest that PKB is required for simvastatinmediated activation of caspase-1.

\section{The small GTPase Rac1 is activated by simvastatin treatment}

In MKD patients, impairment of the isoprenoid biosynthesis pathway induces a shortage of geranylgeranylated proteins. ${ }^{13}$ The majority of geranylgeranylated proteins consist of small GTPases, including proteins of the Rho family. Lack of geranylgeranylation of the small GTPases may cause mislocalization of the protein because they lack the proper membrane localization anchor. Previously, it was assumed that geranylgeranylation is essential for the functioning of $\mathrm{G}$ proteins and lack of this modification would render them inactive. ${ }^{28}$ However, lack of geranylgeranylation may actually cause an overactivity of the protein because, without the geranylgeranyl fatty acid tail, guanine nucleotide dissociation inhibitors (GDIs) can no longer bind and the protein can more easily change to its active GTP-bound state. ${ }^{29,30} \mathrm{We}$ wanted to investigate whether small GTPases are activated by statin treatment and may play a role in activating the PI3K/PKB signal transduction route. A probable candidate would be the small GTPase Rac1 because it was shown previously to be able to act upstream of PI3K. ${ }^{31,32}$ To determine whether Rac1 activity is indeed directly affected by simvastatin treatment, we performed a pulldown assay to establish the amount of GTP-bound, and thus activated, Rac1 (Figure 6). THP-1 cells were cultured in the presence or absence of simvastatin and cell extracts were prepared. The level of GTPbound Rac1 was assessed by Western blot analysis according to the manufacturer's protocol. THP-1 cells treated with simvastatin contained more GTP-bound, and thus active, Rac1 than untreated control cells (Figure 6A). To determine whether the increase in GTP-bound Rac1 was indeed the result of an impairment of the isoprenoid biosynthesis pathway, mevalonate was added to simvastatin-treated cells. Mevalonate is the direct downstream product of HMG-CoA reductase and therefore relieves the inhibition imposed by simvastatin. Addition of mevalonate prevented the activation 
induced by simvastatin (Figure 6B). These results clearly indicate that impairment of the isoprenoid biosynthesis pathway using simvastatin activates the small GTPase Rac1.

\section{The small GTPase Rac1 is required for simvastatin-mediated IL-1 $\beta$ secretion}

To confirm the role of the small GTPase Rac1 in simvastatinmediated IL-1 $\beta$ release, we incubated THP-1 cells with a specific inhibitor of Rac1 either before simvastatin or before LPS incubation (Figure 6C). Inhibition of Rac 1 decreased IL-1 $\beta$ release in a dose-dependent manner when administered before simvastatin.
This effect was abolished when the inhibitor was added after simvastatin but before LPS treatment. These results demonstrate that Rac1 activity is required for statin-mediated enhancement of IL- $1 \beta$ release.

To determine whether Rac1 indeed functioned upstream of both PI3K and PKB, THP-1 cells were incubated with simvastatin in the presence or absence of Rac1 inhibitor and analyzed for the phosphorylation status of PKB (Figure 6D). As observed previously, incubation with simvastatin induced an increase in phosphorylation of $\mathrm{PKB}$, indicating activation. However, when cells were pretreated with Rac1 inhibitor, activation of PKB was inhibited in a
A

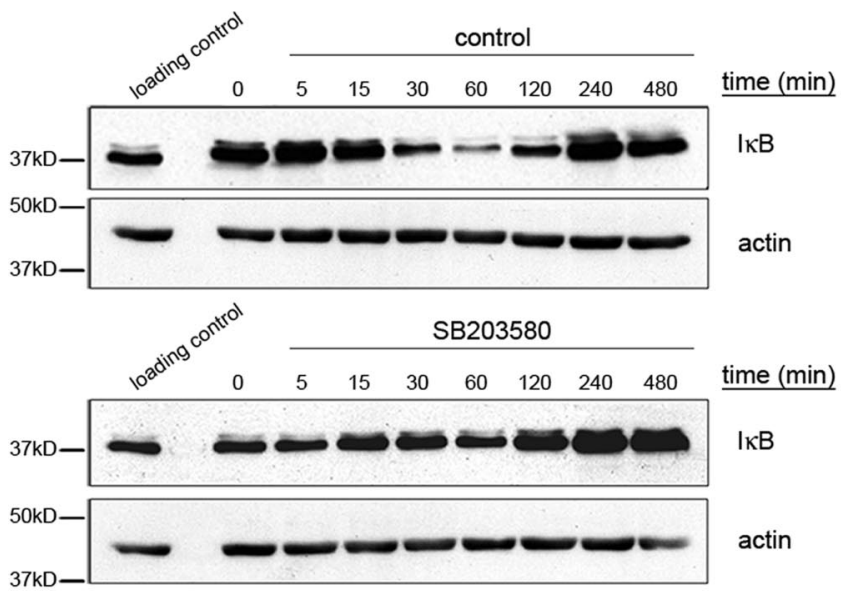

B

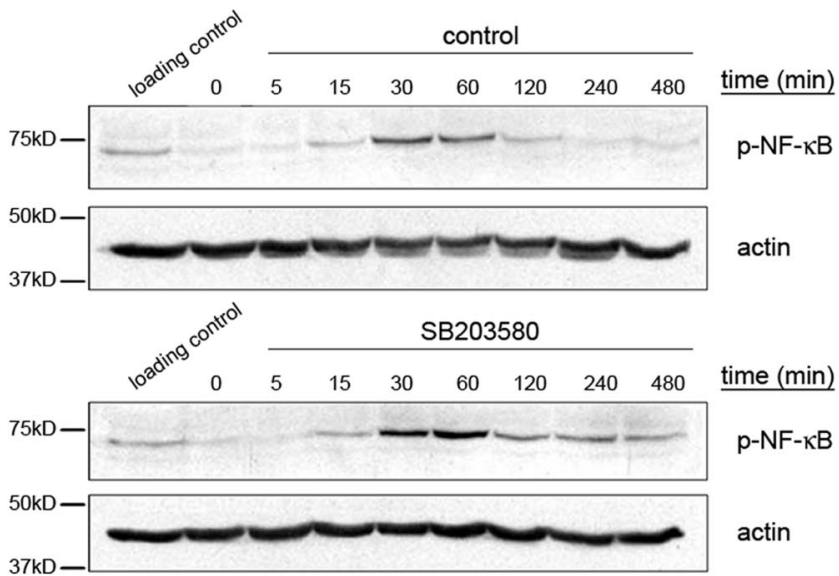

C
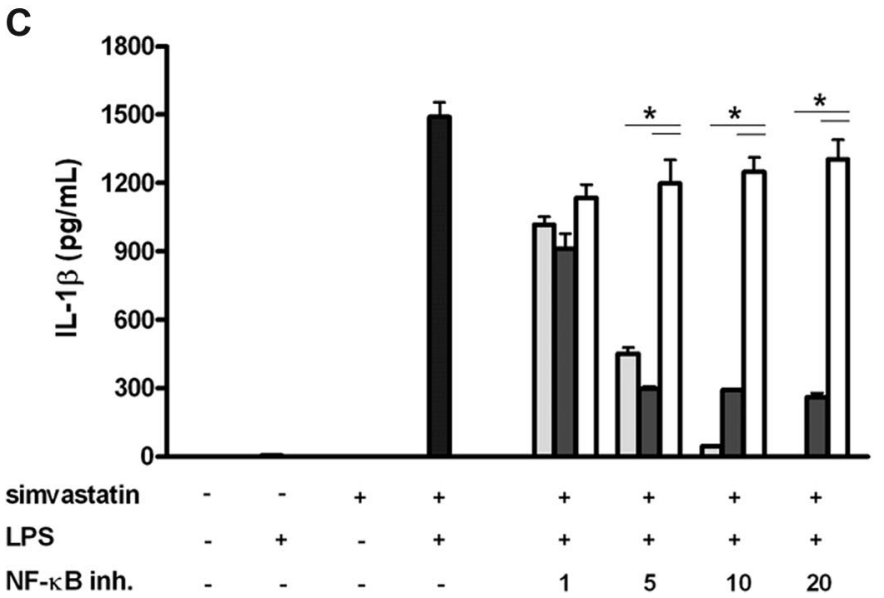

none

$\square \mathrm{CAPE}(\mu \mathrm{g} / \mathrm{mL})$

는 $481408(\mu \mathrm{M})$ 口DMSO
Figure 4. LPS-enhanced transcription of IL-1 $\beta$ is mediated via NF-кB. THP-1 cells were serum-starved overnight and subsequently cultured in the presence of LPS (200 ng/mL) for up to 8 hours. p38 MAPK inhibitor was added 1 hour before LPS treatment. Cells were lysed by adding hot sample buffer $(A)$ or by adding lysis buffer (B). Cell lysates were assayed for phospho-IкB (A) and phospho-NF-кB (B) content. Actin content served as control for equal protein loading. A loading control was prepared to compare between the separate blots. Shown are representative blots of at least 3 independent experiments. (C) THP-1 cells were cultured for 24 hours in the presence or absence of simvastatin $(10 \mu \mathrm{M})$ and stimulated for an additional 4 hours with $200 \mathrm{ng} / \mathrm{mL}$ LPS. The $\mathrm{NF}-\kappa \mathrm{B}$ inhibitors were added 1 hour before LPS treatment. Release of IL-1 $\beta$ was determined by ELISA; data are mean plus or minus SEM $\left(\mathrm{n}=3,{ }^{\star} P<.05\right)$. 
A
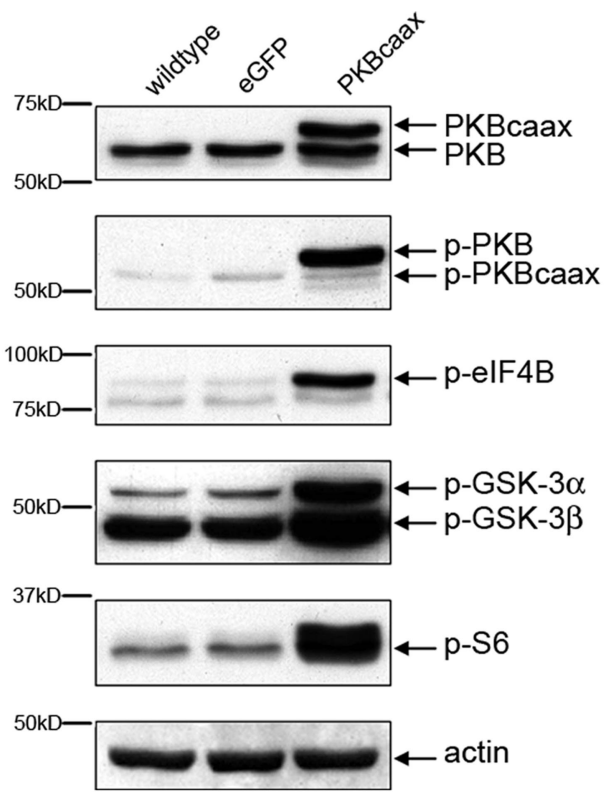

B

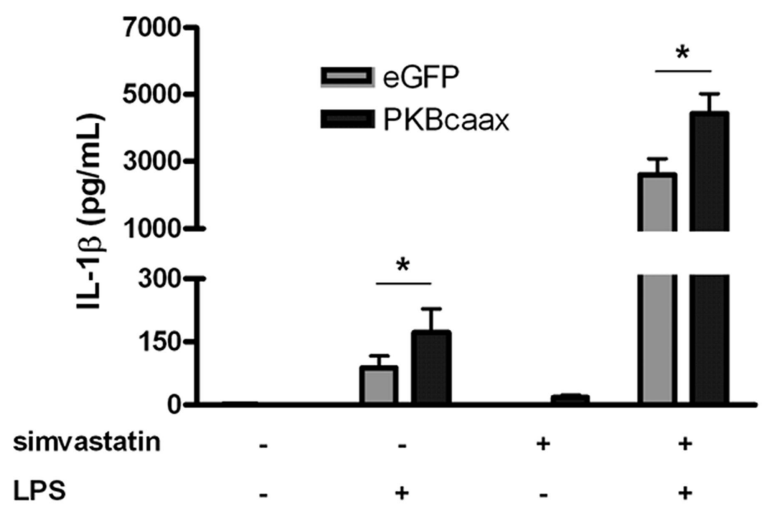

C

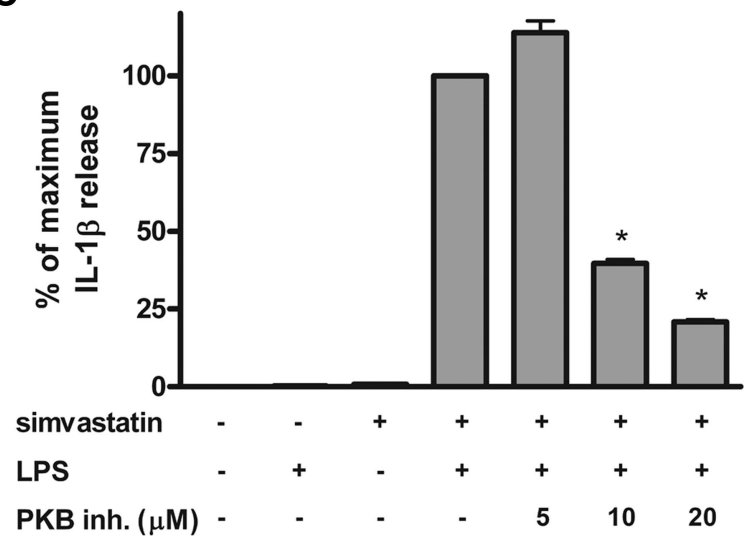

Figure 5. Expression of constitutively active PKB enhances IL-1 $\beta$ secretion. THP-1 cells were virally transduced with either a control vector (eGFP) or a constitutively active form of PKB (PKBcaax). (A) Wild-type and transduced THP-1 cells were serum-starved overnight, after which cell extracts were prepared by adding lysis buffer to the cell pellets. Cell lysates were assayed for phospho-PKB, phospho-elF4B, phospho-GSK-3, phospho-S6, PKB, and actin content. (B) Transduced THP-1 cells were incubated with simvastatin for 24 hours, followed by a 4-hour stimulation with LPS. Release of IL-1 $\beta$ was determined by ELISA; data are mean plus or minus SEM $\left(n=6\right.$; $\left.{ }^{\star} P<.05\right)$. (C) Wild-type THP-1 cells were cultured for 24 hours in the presence or absence of simvastatin $(10 \mu \mathrm{M})$ and stimulated for an additional 4 hours with $200 \mathrm{ng} / \mathrm{mL}$ LPS. PKB inhibitor was added 1 hour before simvastatin treatment at the concentrations indicated. Release of IL-1 $\beta$ was determined by ELISA; data are mean plus or minus SEM $\left(\mathrm{n}=3\right.$; $\left.{ }^{*} P<.01\right)$. dose-dependent manner, illustrating that Rac1 indeed functions upstream of PKB.

\section{PI3K and Rac1 enhance IL-1ß secretion through activation of caspase-1}

Taken together, these data demonstrate that simvastatin treatment can directly activate Rac1 and that Rac1 is required for PKB activation and enhanced IL-1 $\beta$ release. To determine whether increased IL- $1 \beta$ release is mediated via activation of caspase- 1 , we measured caspase-1 p20 subunit levels in culture supernatants of the THP-1 cells as a marker for caspase-1 activation. Active caspase-1 has previously been shown to be localized in a lysosomal compartment within the cell together with proIL-1 $\beta$. On activation, proIL- $1 \beta$ is cleaved in a caspase-1-dependent manner, and both mature IL-1 $\beta$ and the active caspase- 1 subunits are released extracellularly. ${ }^{33}$ In addition, we have previously shown that simvastatin treatment alone and in combination with LPS induces an increase in caspase- 1 p20 subunit secretion in both a time- and dose-dependent manner. ${ }^{19}$ THP-1 cells were cultured as before in the presence or absence of either the PI3K inhibitor LY294002 or the specific Rac1 inhibitor. Both caspase-1 p20 subunit and IL-1 $\beta$ levels in culture supernatant were determined (Figure 7). As demonstrated previously, secretion of IL-1 $\beta$ was only observed when both simvastatin and LPS were present (Figure 7A), whereas incubation with simvastatin alone already increased the release of caspase-1 p20 subunit, indicating activation. This release further increased when LPS was also present (Figure 7B). As observed previously (Figures 1B, 3C), inhibition of PI3K or Rac1 strongly decreased IL- $1 \beta$ secretion, coinciding with a decrease in caspase-1 p20 subunit, both in the simvastatin-only condition as well as the condition where both simvastatin and LPS are present (Figure 7B). The presence of caspase- 1 p20 and IL- $1 \beta$ in the supernatant was not caused by a passive release resulting from cell death as confirmed by a lactate dehydrogenase assay for cell viability (Figure 7C). These results indicate that statin-mediated activation of caspase-1 is dependent on Rac1/PI3K activity.

\section{Simvastatin-induced IL-1 $\beta$ release by healthy and patient PBMCs is Rac1-dependent}

To confirm the primary role of Rac1 in simvastatin-induced IL-1 $\beta$ release in primary cells, we isolated PBMCs from 3 healthy volunteers. Similar to the THP-1 cells, the isolated PBMCs were cultured for 24 hours in the presence of simvastatin, after which they were stimulated with LPS. One hour before simvastatin treatment, the cells were incubated with Rac1 inhibitor at the indicated concentrations. As previously observed for the THP-1 cells, statin/LPS treatment led to a dramatic increase in IL-1 $\beta$ release, whereas treatment with either LPS or simvastatin alone did not (Figure 7D). Rac1 inhibitor decreased this IL-1 $\beta$ release in a dose-dependent manner, indicating that, also in primary cells, statin-induced IL-1 $\beta$ release is Rac1-dependent.

To further confirm these findings, we wanted to establish whether administration of the Rac1 inhibitor would also be able to inhibit IL-1 $\beta$ secretion by PBMCs from MKD patients. PBMCs were isolated from 2 MKD patients. These cells were cultured for 24 hours in the presence or absence of LPS and the Rac1 inhibitor (Figure 7E). As expected, inhibition of Rac1 strongly reduced IL-1 $\beta$ release by MKD PBMCs, suggesting that Rac1 is a potential novel target for therapeutic intervention. 


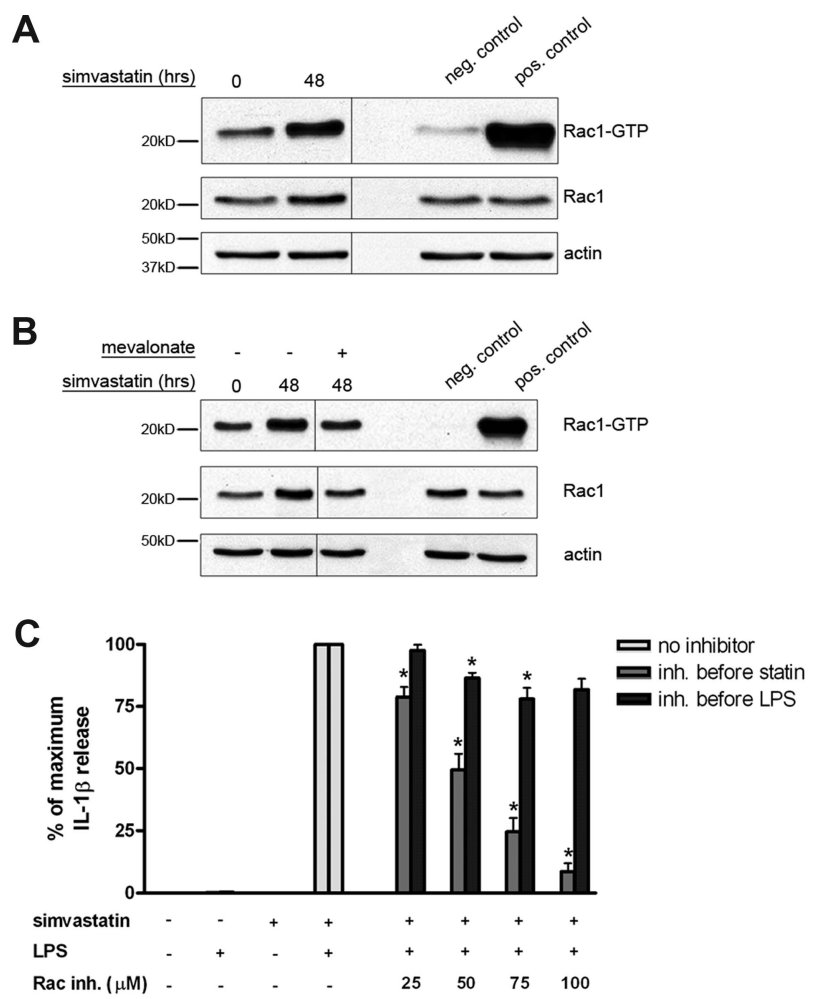

D

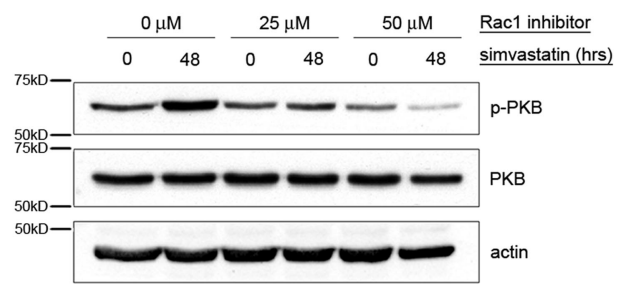

Figure 6. The small GTPase Rac1 is involved in simvastatin-enhanced IL-1 $\beta$ secretion. (A) THP-1 cells were serum-starved overnight and subsequently cultured in the presence or absence of simvastatin $(10 \mu \mathrm{M})$ for 48 hours. GTPase pulldown fractions and cell lysates were assayed for Rac1 content. (B) Mevalonate (1 mM) was added just before simvastatin. Actin content served as control for equal protein loading. Vertical lines have been inserted to indicate a repositioned gel lane, within the same gel. Shown are representative blots of at least 3 independent experiments. (C) THP-1 cells were cultured for 24 hours in the presence or absence of simvastatin $(10 \mu \mathrm{M})$ and stimulated for an additional 4 hours with $200 \mathrm{ng} / \mathrm{mL}$ LPS. Rac1 inhibitor was added either 1 hour before simvastatin or 1 hour before LPS treatment. Release of IL-1 $\beta$ was determined by ELISA; data are mean plus or minus SEM ( $n=5$; ${ }^{\star} P<.01$ ). (D) THP-1 cells were serum-starved overnight and subsequently cultured in the presence or absence of simvastatin $(10 \mu \mathrm{M})$ for 48 hours. Rac1 inhibitor was added 1 hour before simvastatin incubation. After the incubation, cells were lysed by adding lysis buffer and assayed for phospho-PKB and total PKB content. Actin content served as control for equal protein loading. Shown are representative blots of at least 3 independent experiments.

\section{Discussion}

MKD is a metabolic disease, caused by a genetic defect in isoprenoid biosynthesis. ${ }^{4,5}$ Since the identification of mevalonate kinase as the affected enzyme, research has been directed toward elucidating the molecular mechanism underlying mevalonate kinase deficiency-induced inflammation. Previous studies have established that patient PBMCs secrete very high levels of IL-1 $\beta$ on endotoxin stimulation compared with healthy PBMCs ${ }^{12,13}$ and that this is thought to be caused by a lack of nonsterol isoprenoid products, specifically of geranylgeranyl-pyrophosphate. ${ }^{10-13}$ Indeed, we have recently shown that a shortage of geranylgeranylated proteins leads to activation of caspase-1, the enzyme responsible for processing proIL-1 $\beta$ into the active and secreted form. ${ }^{19}$ This suggests that an impaired isoprenoid biosynthesis pathway results in hyperactive caspase-1. Where healthy monocytic cells would respond to pattern-associated molecular patterns, such as LPS, or damage-associated molecular patterns by generating intracellular stores of proIL-1 $\beta$ protein, ${ }^{34,35}$ cells containing hyperactive caspase- 1 would process the generated proIL-1 $\beta$ protein and release the pro-inflammatory, mature IL-1 $\beta$ in a dysregulated manner. This hypothesis provides a rationale for inflammation in mevalonate kinase deficiency: patients have hyperactive caspase-1 because of a shortage of geranylgeranylated proteins and will inappropriately secrete IL- $1 \beta$ whenever they come into contact with pattern-associated molecular patterns or damage-associated molecular patterns resulting in inflammation and fever attacks.

In this study, we investigated the molecular mechanisms underlying simvastatin-mediated activation of caspase-1. Because of the extremely limited number of patients, we have previously described a model using THP-1 monocytic cells to study the disease mechanism in more detail. ${ }^{19}$ Using this model, we have now demonstrated that PI3K and Rac1 are required for simvastatinmediated IL-1 $\beta$ secretion through regulation of caspase- 1 activity (Figures 1B, 6C, and 7B), which was confirmed in primary cells (Figure 7D). One of the major intracellular mediators of PI3K activation is $\mathrm{PKB} .{ }^{22}$ Indeed, we have shown that simvastatin activates PKB (Figure 2) and that ectopic expression of constitutively active PKB significantly increases IL-1 $\beta$ secretion after LPS challenge in the presence as well as in the absence of HMG-CoA reductase activity (Figure 2). Furthermore, Rac1 activity was shown to increase on simvastatin treatment and to act upstream of PKB (Figure 3). We therefore propose a molecular mechanism for IL-1 $\beta$ release, in which simvastatin activates Rac1, which subsequently activates a $\mathrm{PI} 3 \mathrm{~K} / \mathrm{PKB}$-dependent pathway resulting in activation of caspase- 1 .

In addition to the simvastatin-mediated activation of caspase-1, we have demonstrated that $\mathrm{p} 38 \mathrm{MAPK}$ and $\mathrm{NF}-\kappa \mathrm{B}$ are required for LPS-induced IL-1 $\beta$ transcription (Figures 1B, 4A,C). However, inhibition of IL-1 $\beta$ release by the p38 MAPK inhibitor was not dose-dependent and p38 MAPK inhibition also resulted in a delay, rather than complete inhibition, of IL-1 $\beta$ transcription (Figure 3), indicating that additional factors might play a role. These data imply that IL- $1 \beta$ transcription is primarily regulated by $\mathrm{p} 38$ MAPK, but other factors possibly contribute, or substitute for p38 MAPK when it is inhibited. Exactly which other factors might be involved remains to be investigated.

Taken together, our data demonstrate that artificial inhibition of the isoprenoid biosynthesis pathway leads to activation of caspase-1. This occurs via activation of the small GTPase Rac1. Exactly how simvastatin treatment induces activation of Rac1 is not entirely clear. However, as previously described, impaired binding of GDIs may result in more rapid switching between GDP- and GTP binding by Rac1, leading to a net increase in activity. The importance of Rac1 in the processing and release of IL-1 $\beta$ is confirmed by the previous finding that Yersinia bacteria can prevent host IL-1 $\beta$ release by targeting Rac $1 .^{36}$ The Yersinia protein YopE is a GTPase-activating protein, which accelerates GTP hydrolysis, thereby switching off the small GTPases Rho, Rac, and cdc42. Macrophages infected with a YopE knockout Yersinia enterolitica strain, so with increased GTPase activity compared with wild-typeinfected cells, released significantly higher levels of IL-1 $\beta$. Furthermore, overexpression of YopE, but not of a catalytically inactive mutant of YopE, inhibited autoprocessing of caspase-1 as well as 
processing of proIL-1 $\beta$. These data correlate with our own findings that increased Rac1 activity enhances caspase-1 processing of pro-IL1 $\beta$.

Our data show that Rac1, PI3K, and PKB mediate simvastatinenhanced IL-1 $\beta$ secretion. PI3K has been described to serve as an activator as well as an effector of Rac1. ${ }^{37,38}$ Lipid products derived from activated PI3K can activate guanine nucleotide-exchange factors for Rac1, thereby activating Rac1, or active Rac1 can regulate the activation and localization of PI3K by binding to its p85 subunit. We demonstrated that Rac1 functions upstream of PKB (Figure 6D) and that PI3K is required for phosphorylation of

\section{A}

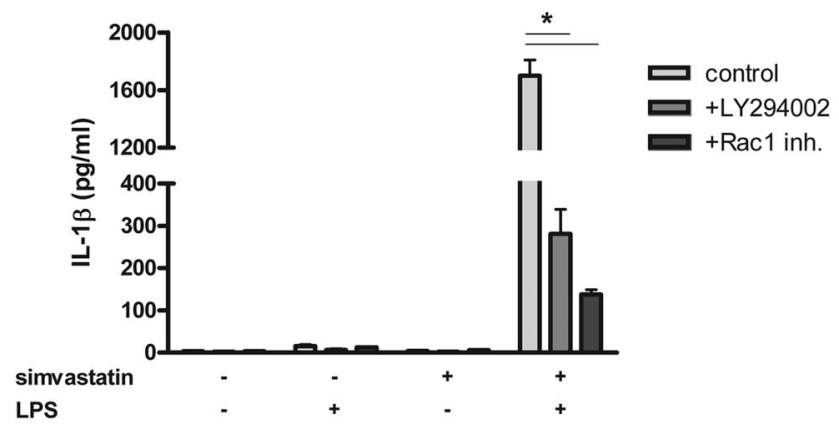

C

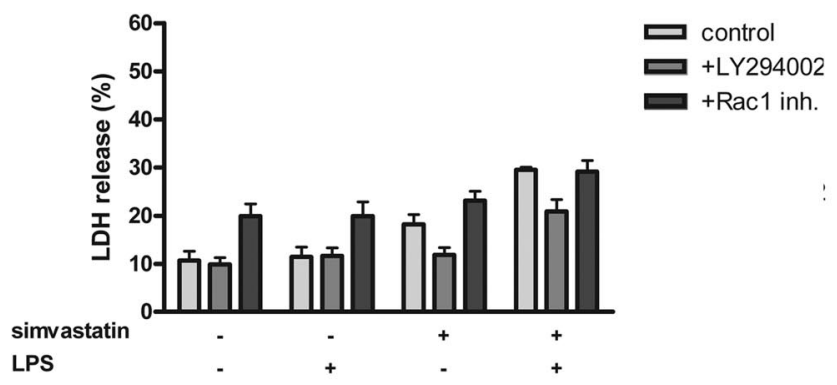

E
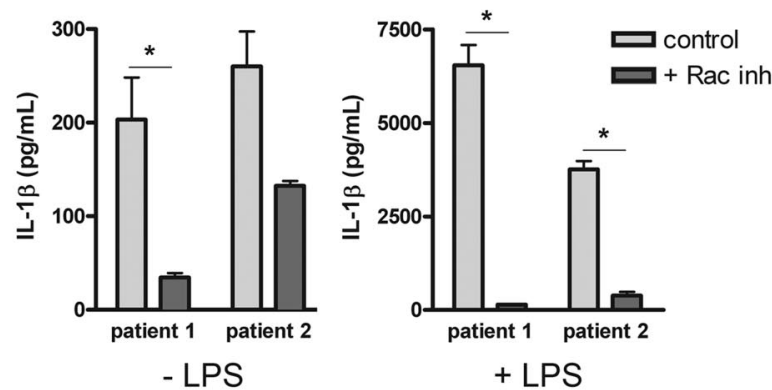

PKB (Figure 2B), suggesting the sequential activation of Rac1, $\mathrm{PI} 3 \mathrm{~K}$, and PKB.

A major question that remains is how PKB activity can regulate caspase- 1 autoprocessing. Caspase- 1 is synthesized as an inactive zymogen of approximately $45 \mathrm{kDa}$ that, via induced proximity to another caspase-1 zymogen, can undergo autocleavage, creating $10-\mathrm{kDa}$ and $20-\mathrm{kDa}$ subunits. Two p10 and two p20 subunits form the fully functional heterodimeric enzyme. Caspase-1 autoactivates itself in a complex of proteins termed the inflammasome. ${ }^{39}$ Caspase-1 contains an N-terminal caspase recruitment domain (CARD), which forms a homotypic interaction (CARD-CARD

B

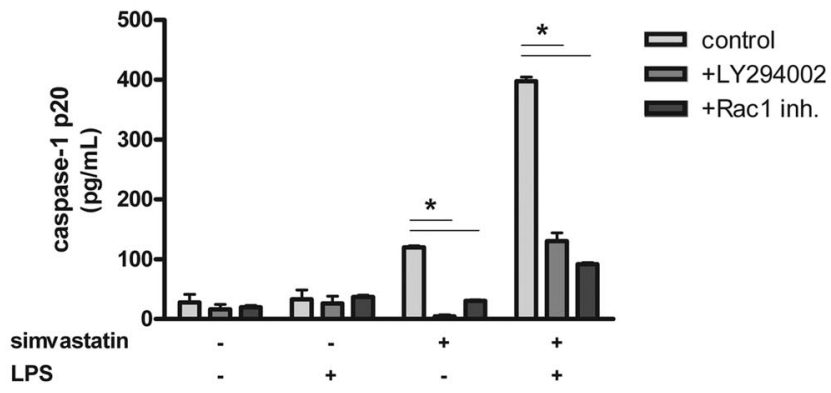

D
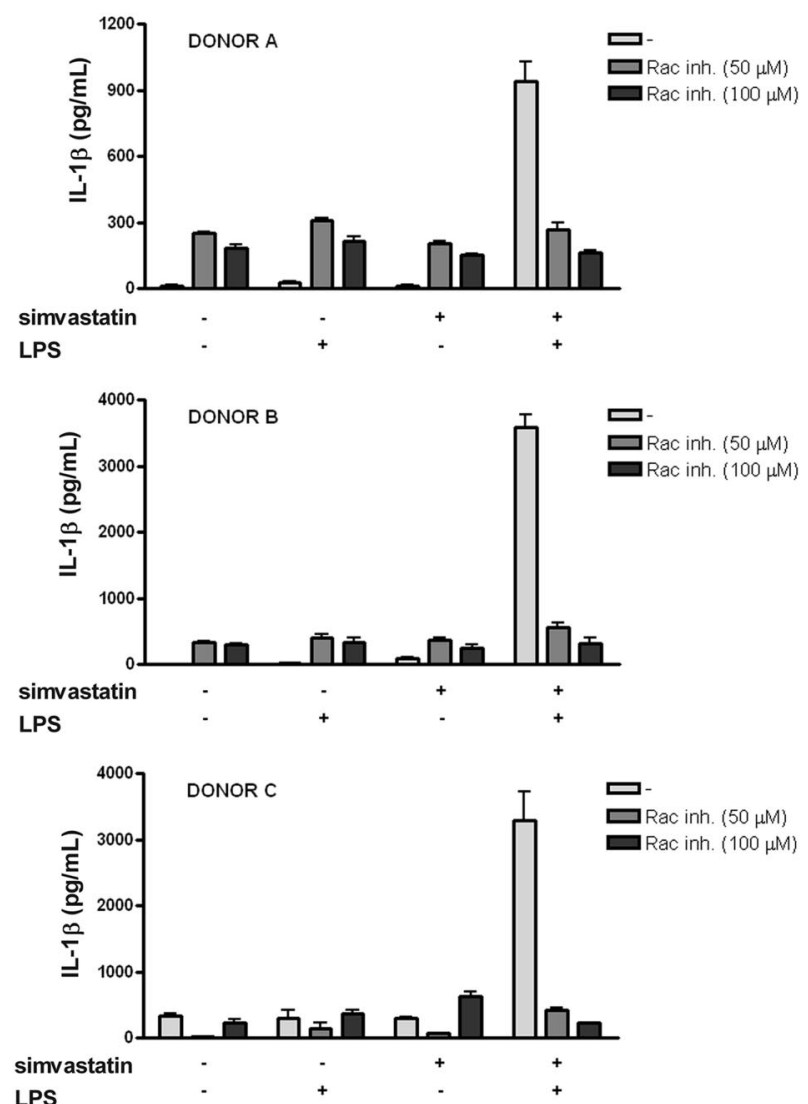

Figure 7. Rac1 regulates IL-1 $\beta$ release by MKD PBMCs. THP-1 cells were cultured for 24 hours in the presence or absence of simvastatin (20 $\mu$ M) and stimulated for an additional 4 hours with $200 \mathrm{ng} / \mathrm{mL}$ of LPS. Rac1 inhibitor and PI3K inhibitor were added 1 hour before simvastatin treatment. Release of IL-1 $\beta$ (A) and caspase-1 p20 (B) was determined by ELISA; data are mean plus or minus SEM ( $n=6$ for control and PI3K inhibitor-treated samples, $n=3$ for Rac1 inhibitor-treated samples, $\left.{ }^{\star} P<.05\right)$. (C) Cell viability was determined by a lactic dehydrogenase assay $\left(n=3 ;{ }^{*} P<.05\right)$. (D) PBMCs of 3 healthy controls were cultured for 24 hours in the presence or absence of simvastatin $(10 \mu \mathrm{M})$, followed by 24 hours of LPS stimulation $(500 \mathrm{ng} / \mathrm{mL})$. One hour before simvastatin treatment, the cells were incubated with the indicated concentrations of Rac inhibitor. Release of IL-1 $\beta$ was determined by ELISA; data are mean plus or minus SEM $(n=3)$. (E) PBMCs of 2 patients were cultured for 24 hours in the absence or presence of $500 \mathrm{ng} / \mathrm{mL}$ of LPS. Patient cells were incubated with $100 \mu \mathrm{M}$ of Rac1 inhibitor 1 hour before LPS stimulation. Release of IL- $1 \beta$ was determined by ELISA; data are mean plus or minus SEM $\left(n=3, n=2\right.$ for patient $\left.2,{ }^{\star} P<.05\right)$. 
interaction) with apoptosis-associated speck-like protein containing a CARD (ASC). This adaptor protein interacts with other members of the inflammasome ${ }^{40}$ via similar homotypic interactions, enabling oligomerization, and autocleavage of caspase-1. Active caspase- 1 is thought to colocalize with proIL-1 $\beta$ in lysosomal compartments, in which processing of proIL-1 $\beta$ into mature IL- $1 \beta$ takes place. ${ }^{33}$ Mature IL- $1 \beta$ and the active caspase- 1 subunits are subsequently released into the extracellular environment. Because caspase- 1 is activated in a multiprotein complex, PKB-enhanced activation of caspase- 1 does not necessarily have to involve direct interactions with caspase-1; interactions with other members of the inflammasome could also be responsible for enhanced activation.

A possible connection between PKB and caspase- 1 activation is the p21-activated kinase 1 (Pak1). This protein was shown to be activated by $\operatorname{Rac}^{41}$ and can directly bind to and phosphorylate caspase- 1 on serine $376 .{ }^{42}$ Although the function of caspase- 1 phosphorylation remains unclear, phosphorylation of this residue appears essential to caspase- 1 activity because caspase- 1 activation was abrogated in LPS-stimulated THP-1 cells transfected with an S376A mutant. In addition, PI3K has been demonstrated to associate with the $\mathrm{N}$-terminal regulatory domain of Pak1, leading to Pak1 activation, ${ }^{43}$ and PKB was found to phosphorylate Pak1 on serine 21, which enables Pak1 to bind to the adaptor protein Nck. ${ }^{44}$

Possibly, PKB-mediated activation of caspase-1 involves cytoskeletal rearrangements. $\mathrm{PKB}$ has been described to bind directly to actin via its $\mathrm{N}$-terminal $\mathrm{PH}$ domain. ${ }^{45}$ In addition, Rac1mediated inhibition of caspase-1 by the Yersinia protein YopE was found to be mediated by LIM kinase-1 (LIMK1), which targets the actin cytoskeleton. ${ }^{36}$ Indeed, overexpression of constitutive-active LIMK1 promoted activation of caspase-1, whereas dominantnegative LIMK1 could abrogate Rac1-induced activation of caspase-1, suggesting that Rac1-mediated phosphorylation of the actin cytoskeleton is necessary for caspase- 1 activation. A potential role for cytoskeletal rearrangements in activation of caspase- 1 is also suggested by the molecular mechanism underlying Familial Mediterranean Fever and PAPA syndrome. These 2 autoinflammatory syndromes are strongly related to mevalonate kinase deficiency, with very similar symptoms and also thought to be caused by inappropriate release of IL- $1 \beta .{ }^{46,47}$ PAPA syndrome is caused by mutations in the cytoskeleton-organizing protein PSTPIP1. PSTPIP1 can activate the actin-binding protein pyrin, which is the protein affected in Familial Mediterranean Fever. Mutations of both PSTPIP1 and pyrin were shown to facilitate the assembly of multiprotein complexes capable of activating caspase-1. However, a defined role for cytoskeletal rearrangements in activation of caspase-1 requires further research.
The data described in this study demonstrate that simvastatinmediated IL-1 $\beta$ release is mediated via a Rac1/PI3K/PKBdependent signal transduction pathway. Whether this signal transduction pathway is also involved in other (auto)inflammatory disorders remains to be investigated. However, the fact that spontaneous activation of caspase- 1 seems to be a common mechanism of inflammation suggests that similar pathways may be involved. Currently, treatment of MKD consists mostly of nonsteroidal anti-inflammatory drugs, and more recently cytokinetargeted therapies have been tried (anti-tumor necrosis factor- $\alpha$ and IL-1 receptor antagonist) with various success. These therapies are, however, very costly and do not benefit all patients. The data presented in this study identify Rac1 as a possible new target for MKD therapy (Figure 7D). Interestingly, Rac inhibitors are currently under investigation for use in cancer therapy. Especially, the development of a novel compound that targets a Rac specific guanine nucleotide-exchange factor (NSC23766) appears promising as a Rac specific small molecule inhibitor. This compound was shown to suppress proliferation and the invasive phenotype of prostate tumor cells ${ }^{48}$ and could effectively block Rac GTPase activity after intraperitoneal administration to laboratory mice. ${ }^{49}$ Other approaches for targeted inhibition of Rac1 include inhibition of Rac effector binding and stabilization of Rac-RhoGDI complexes. ${ }^{50}$

In conclusion, our data demonstrate that inhibition of Rac1 can strongly reduce IL-1 $\beta$ release by THP-1 cells and healthy and MKD PBMCs through inhibition of caspase-1 activation. These data suggest that Rac1 inhibition may provide a novel therapeutic strategy for the treatment of MKD.

\section{Acknowledgments}

L.M.K. was supported by the Wilhelmina Children's Hospital Research Fund.

\section{Authorship}

Contribution: L.M.K. designed and performed research, analyzed data, and wrote the manuscript; J.M.B. performed experiments and provided helpful discussion and advice; J.K. performed lightcycler experiments and analyzed the data; H.R.W. provided helpful discussion and advice; and J.F. and P.J.C. designed the research, contributed patient samples and wrote the manuscript.

Conflict-of-interest disclosure: The authors declare no competing financial interests.

Correspondence: Paul J. Coffer, Lundlaan 6, 3584 EA Utrecht, The Netherlands; e-mail: p.j.coffer@umcutrecht.nl.

\section{References}

1. Frenkel J, Houten SM, Waterham HR, et al. Clinical and molecular variability in childhood periodic fever with hyperimmunoglobulinaemia D. Rheumatology (Oxf). 2001;40:579-584.

2. Drenth JP, Haagsma CJ, van der Meer JW. Hyperimmunoglobulinemia $\mathrm{D}$ and periodic fever syndrome: the clinical spectrum in a series of 50 patients. International Hyper-IgD Study Group. Medicine (Baltimore). 1994;73:133-144

3. Frenkel J, Houten SM, Waterham HR, et al. Mevalonate kinase deficiency and Dutch type periodic fever. Clin Exp Rheumatol. 2000;18:525-532.

4. Houten SM, Kuis W, Duran M, et al. Mutations in MVK, encoding mevalonate kinase, cause hyper- immunoglobulinaemia $D$ and periodic fever syndrome. Nat Genet. 1999;22:175-177.

5. Drenth JP, Cuisset L, Grateau G, et al. Mutations in the gene encoding mevalonate kinase cause hyper-lgD and periodic fever syndrome: International Hyper-IgD Study Group. Nat Genet. 1999; 22:178-181.

6. Houten SM, Frenkel J, Waterham HR. Isoprenoid biosynthesis in hereditary periodic fever syndromes and inflammation. Cell Mol Life Sci. 2003, 60:1118-1134

7. Goldstein JL, Brown MS. Regulation of the mevaIonate pathway. Nature. 1990;343:425-430.

8. Clarke S. Protein isoprenylation and methylation at carboxyl-terminal cysteine residues. Annu Rev Biochem. 1992;61:355-386.

9. Moores SL, Schaber MD, Mosser SD, et al. Sequence dependence of protein isoprenylation. J Biol Chem. 1991;266:14603-14610.

10. Montero MT, Matilla J, Gomez-Mampaso E, Lasuncion MA. Geranylgeraniol regulates negatively caspase-1 autoprocessing: implication in the Th1 response against Mycobacterium tuberculosis. J Immunol. 2004;173:49364944.

11. Montero MT, Hernandez $O$, Suarez $Y$, et al. Hydroxymethylglutaryl-coenzyme A reductase inhibition stimulates caspase-1 activity and Th1-cytokine 
release in peripheral blood mononuclear cells. Atherosclerosis. 2000;153:303-313.

12. Frenkel J, Rijkers GT, Mandey SH, et al. Lack of isoprenoid products raises ex vivo interleukin1 beta secretion in hyperimmunoglobulinemia D and periodic fever syndrome. Arthritis Rheum. 2002;46:2794-2803.

13. Mandey SH, Kuijk LM, Frenkel J, Waterham HR. A role for geranylgeranylation in interleukin-1beta secretion. Arthritis Rheum. 2006;54:3690-3695.

14. Rigante D, Ansuini V, Bertoni B, et al. Treatment with anakinra in the hyperimmunoglobulinemia D/periodic fever syndrome. Rheumatol Int. 2006; 27:97-100.

15. Nevyjel M, Pontillo A, Calligaris L, et al. Diagnostics and therapeutic insights in a severe case of mevalonate dinase deficiency. Pediatrics. 2007; 119:e523-e527.

16. Lequerre T, Vittecoq $O$, Pouplin $S$, et al. Mevalonate kinase deficiency syndrome with structural damage responsive to anakinra. Rheumatology (Oxf). 2007;46:1860-1862.

17. Fenton MJ, Clark BD, Collins KL, et al. Transcriptional regulation of the human prointerleukin 1 beta gene. J Immunol. 1987;138:3972-3979.

18. Hirschfeld M, Weis JJ, Toshchakov V, et al. Signaling by toll-like receptor 2 and 4 agonists results in differential gene expression in murine macrophages. Infect Immun. 2001;69:1477-1482.

19. Kuijk LM, Mandey SH, Schellens I, et al. Statin synergizes with LPS to induce IL-1beta release by THP-1 cells through activation of caspase-1. Mol Immunol. 2008;45:2158-2165.

20. Buitenhuis M, Verhagen LP, van Deutekom HW, et al. Protein kinase B (C-AKT) regulates hematopoietic lineage choice decisions during myelopoiesis. Blood. 2007;111:112-121.

21. Geijsen N, van Delft S, Raaijmakers JA, et al. Regulation of p21 rac activation in human neutrophils. Blood. 1999;94:1121-1130.

22. Burgering BM, Coffer PJ. Protein kinase B (c-Akt) in phosphatidylinositol-3-OH kinase signal transduction. Nature. 1995;376:599-602.

23. Fenton MJ, Vermeulen MW, Clark BD, Webb AC, Auron PE. Human pro-IL-1 beta gene expression in monocytic cells is regulated by two distinct pathways. J Immunol. 1988;140:2267-2273.

24. Calleros L, Lasa M, Toro MJ, Chiloeches A. Low cell cholesterol levels increase NFkappaB activity through a p38 MAPK-dependent mechanism. Cell Signal. 2006;18:2292-2301.

25. Kim SJ, Hwang SG, Shin DY, Kang SS, Chun JS. p38 kinase regulates nitric oxide-induced apoptosis of articular chondrocytes by accumulating p53 via NFkappa B-dependent transcription and sta- bilization by serine 15 phosphorylation. J Biol Chem. 2002;277:33501-33508.

26. Li Q, Verma IM. NF-kappaB regulation in the immune system. Nat Rev Immunol. 2002;2:725734.

27. Ribaux PG, Iynedjian PB. Analysis of the role of protein kinase $B$ (cAKT) in insulin-dependent induction of glucokinase and sterol regulatory element-binding protein 1 (SREBP1) mRNAs in hepatocytes. Biochem J. 2003;376:697-705.

28. Rando RR. Chemical biology of protein isoprenylation/methylation. Biochim Biophys Acta. 1996; 1300:5-16.

29. Cordle A, Koenigsknecht-Talboo J, Wilkinson B, Limpert A, Landreth G. Mechanisms of statinmediated inhibition of small G-protein function. J Biol Chem. 2005;280:34202-34209.

30. Turner SJ, Zhuang S, Zhang T, Boss GR, Pilz RB Effects of lovastatin on Rho isoform expression, activity, and association with guanine nucleotide dissociation inhibitors. Biochem Pharmacol. 2007;75:405-413.

31. Arbibe L, Mira JP, Teusch N, et al. Toll-like receptor 2-mediated NF-kappa B activation requires a Rac1-dependent pathway. Nat Immunol. 2000;1: 533-540.

32. Harokopakis E, Albzreh MH, Martin MH, Hajishengallis $\mathrm{G}$. TLR2 transmodulates monocyte adhesion and transmigration via Rac1- and PI3Kmediated inside-out signaling in response to Porphyromonas gingivalis fimbriae. J Immunol. 2006 176:7645-7656.

33. Andrei C, Margiocco P, Poggi A, et al. Phospholipases $C$ and $A 2$ control lysosome-mediated IL1beta secretion: Implications for inflammatory processes. Proc Natl Acad Sci U S A. 2004;101: 9745-9750.

34. Mehta VB, Hart J, Wewers MD. ATP-stimulated release of interleukin (IL)-1beta and IL-18 requires priming by lipopolysaccharide and is independent of caspase-1 cleavage. J Biol Chem. 2001;276:3820-3826

35. Gery I, Davies P, Derr J, Krett N, Barranger JA. Relationship between production and release of lymphocyte-activating factor (interleukin 1) by murine macrophages: 1 . Effects of various agents. Cell Immunol. 1981;64:293-303.

36. Schotte P, Denecker G, Van Den Broeke A, et al. Targeting Rac 1 by the Yersinia effector protein YopE inhibits caspase-1 mediated maturation and release of interleukin-1beta (IL-1beta). J Biol Chem. 2004;279:25134-25142.

37. Sanchez-Martin L, Sanchez-Sanchez N, Gutierrez-Lopez MD, et al. Signaling through the leukocyte integrin LFA-1 in T cells induces a transient activation of Rac- 1 that is regulated by Vav and PI3K/Akt-1. J Biol Chem. 2004;279:1619416205.

38. Welch HC, Coadwell WJ, Stephens LR, Hawkins PT. Phosphoinositide 3-kinase-dependent activation of Rac. FEBS Lett. 2003;546:93-97.

39. Martinon F, Burns K, Tschopp J. The inflammasome: a molecular platform triggering activation of inflammatory caspases and processing of prolL-beta. Mol Cell. 2002;10:417-426.

40. Srinivasula SM, Poyet JL, Razmara M, et al. The PYRIN-CARD protein ASC is an activating adaptor for caspase-1. J Biol Chem. 2002;277:2111921122.

41. Manser E, Leung T, Salihuddin H, Zhao ZS, Lim L. A brain serine/threonine protein kinase activated by Cdc42 and Rac1. Nature. 1994;367:4046.

42. Basak C, Pathak SK, Bhattacharyya A, et al. NFkappaB- and C/EBPbeta-driven interleukin-1beta gene expression and PAK1-mediated caspase-1 activation play essential roles in interleukin-1beta release from Helicobacter pylori lipopolysaccharide-stimulated macrophages. J Biol Chem. 2005; 280:4279-4288.

43. Papakonstanti EA, Stournaras C. Association of PI-3 kinase with PAK1 leads to actin phosphorylation and cytoskeletal reorganization. Mol Biol Cell. 2002;13:2946-2962.

44. Zhou GL, Zhuo Y, King CC, et al. Akt phosphory lation of serine 21 on Pak1 modulates Nck binding and cell migration. Mol Cell Biol. 2003;23: 8058-8069.

45. Cenni V, Sirri A, Riccio M, et al. Targeting of the Akt/PKB kinase to the actin skeleton. Cell Mol Life Sci. 2003;60:2710-2720.

46. Chae JJ, Komarow HD, Cheng J, et al. Targeted disruption of pyrin, the FMF protein, causes heightened sensitivity to endotoxin and a defect in macrophage apoptosis. Mol Cell. 2003;11:591604.

47. Shoham NG, Centola M, Mansfield E, et al. Pyrin binds the PSTPIP1/CD2BP1 protein, defining familial Mediterranean fever and PAPA syndrome as disorders in the same pathway. Proc Natl Acad Sci U S A. 2003;100:13501-13506.

48. Gao Y, Dickerson JB, Guo F, Zheng J, Zheng Y. Rational design and characterization of a Rac GTPase-specific small molecule inhibitor. Proc Natl Acad Sci U S A. 2004;101:7618-7623.

49. Nassar N, Cancelas J, Zheng J, Williams DA, Zheng Y. Structure-function based design of small molecule inhibitors targeting Rho family GTPases. Curr Top Med Chem. 2006;6:1109-1116.

50. Fritz G, Kaina B. Rho GTPases: promising cellular targets for novel anticancer drugs. Curr Cancer Drug Targets. 2006;6:1-14. 